\section{NONLINEAR DYNAMIC ANALYSIS OF TWO STOREY RC BUILDING MODEL}

\author{
Syed Muhammad Bilal Haidera, Zafarullah Nizamania*, Chun-Chieh \\ Yip ${ }^{b}$, Jing-Ying Wong ${ }^{c}$
}

aDepartment of Environmental Engineering, Universiti Tunku Abdul Rahman, 31900 Kampar, Malaysia

bDepartment of Civil Engineering, Universiti Tunku Abdul Rahman, 43000 Kajang, Selangor, Malaysia

'Department of Civil Engineering, University of Nottingham
Article history

Received

9 December 2020

Received in revised form

5 April 2021

Accepted

20 April 2021

Published online

20 June 2021

*Corresponding author zafarullah@utar.edu.my Malaysia, 43500 Selangor, Malaysia

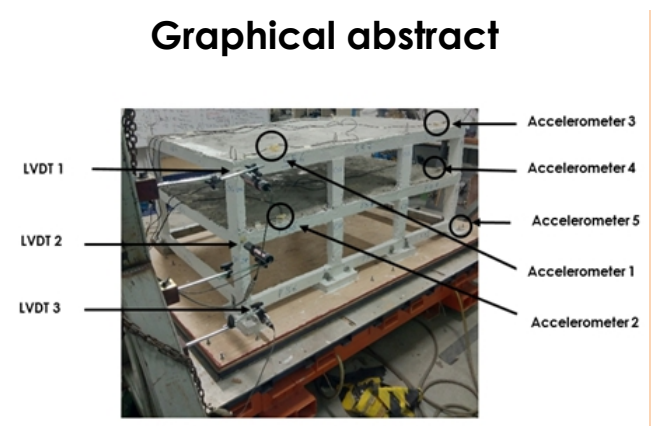

\begin{abstract}
Peninsular Malaysia lies in a low seismic zone, but its building structures had come across the concrete deterioration due to the seismic ground motion originated from far or near field. Notably, most of the building structures in this country are designed based on wind load only. Moreover, current practice to analyze or design a building such as FEMA 368 and EC8 underestimated the effect of repeated excitations. These guidelines only considered single vibrations to evaluate the framed structure. Therefore, the objective of this study was to assess the performance of private educational institute reinforced concrete building with generic 3D two storey frame structure under multiple seismic motions. Structural model was examined under series of earthquake motions which include pre-shock, main shock and aftershock scenario. Total of 7 seismic ground motions were selected to quantify the structural frame model by nonlinear dynamic time history analyses. Pseudo-dynamic ground motions were recorded on shaking table ranging from $0.18 \mathrm{~g}$ to $0.82 \mathrm{~g}$ were applied onto the building model for assessment. The outcome of this study has identified that the low-rise building model survived at higher PGA values. Moderate damages $(0.25 \leq \mathrm{DI}<$ 0.40 ) were recorded after passing through multiple ground motions. Moreover, low seismic vibrations with large ground movement had caused ground floor storey act as soft storey. The study concluded that low rise building model had higher tendency to absorb lower to higher ' $g$ ' values and resist the earthquake loading due to the strength of framed structure.
\end{abstract}

Keywords: Nonlinear dynamic analyses, Reinforced Concrete Framed Structure, Multiple Seismic ground motions, Shaking table, Eurocode

\begin{abstract}
Abstrak
Semenanjung Malaysia berada dalam zon seismik yang rendah tetapi bangunan konkritnya telah mengalami kerosakan disebabkan oleh gegaran tanah seismik dari medan jauh atau dekat. Terutamanya, kebanyakan struktur bangunan di negara ini telah direkakan berdasarkan beban daripada angin sahaja. Lebih-lebih lagi, amalan semasa dalam analisis atau rekaan pada bangunan seperti FEMA 368 dan EC8 telah menganggar rendah kesan gempa berulangan. Garis panduan ini hanya mempertimbangkan getaran tunggal dalam menilai sesebuah struktur bangunan. Oleh itu, objektif kajian ini adalah untuk menilai prestasi sesebuah bangunan konkrit bertetulang besi institusi pendidikan swasta berdasarkan generik 3D dua tingkat kerangka struktur di bawah pelbagai gegaran seismik. Struktur model yang telah diujikaji di bawah siri gegaran gempa bumi merangkumi pra-kejutan, kejutan utama dan senario susulan gempa bumi. Sejumlah 7 gegaran seismik telah terpilih untuk menilai kerangka struktur dengan analisis sejarah masa dinamik tidak linear. Gerakan tanah semu-dinamik yang dicatatkan pada meja gegaran antara $0.18 \mathrm{~g}$
\end{abstract}


kepada $0.82 \mathrm{~g}$ telah digunakan untuk penilaian struktur bangunan. Hasil kajian ini telah mendapati model bangunan rendah mampu bertahan pada nilai PGA yang lebih tinggi. Kerosakan sederhana $(0.25 \leq \mathrm{DI}<0.40)$ telah dicatatkan selepas melalui pelbagai pegerakan tanah. Di samping itu, getaran seismik rendah dengan pergerakan tanah yang besar telah menyebabkan tingkat bawah bertindak sebagai tingkat lembut. Kajian ini telah menyimpulkan bahawa model bangunan bertingkat rendah mampu menyerap nilai ' $g$ ' dari rendah ke tinggi serta dapat menahan beban gempa bumi yang berasaskan kekuatan bingkai struktur.

Kata kunci: Analisis dinamik tidak lelurus, Struktur Bingkai Konkrit Bertetulang, Pelbagai gerakan tanah Seismik, Meja Goncang, Eurocode

(C) 2021 Penerbit UTM Press. All rights reserved

\subsection{INTRODUCTION}

Malaysia is placed to the brink of Eurasian plate which is near to two active seismic plate boundaries. In the west, country is close to Indo-Australian and Eurasian plates. Moreover in the east, Malaysia is surrounded by Eurasian and Philippine plate [1]. Malaysia is located far away from active seismic fault lines [2].

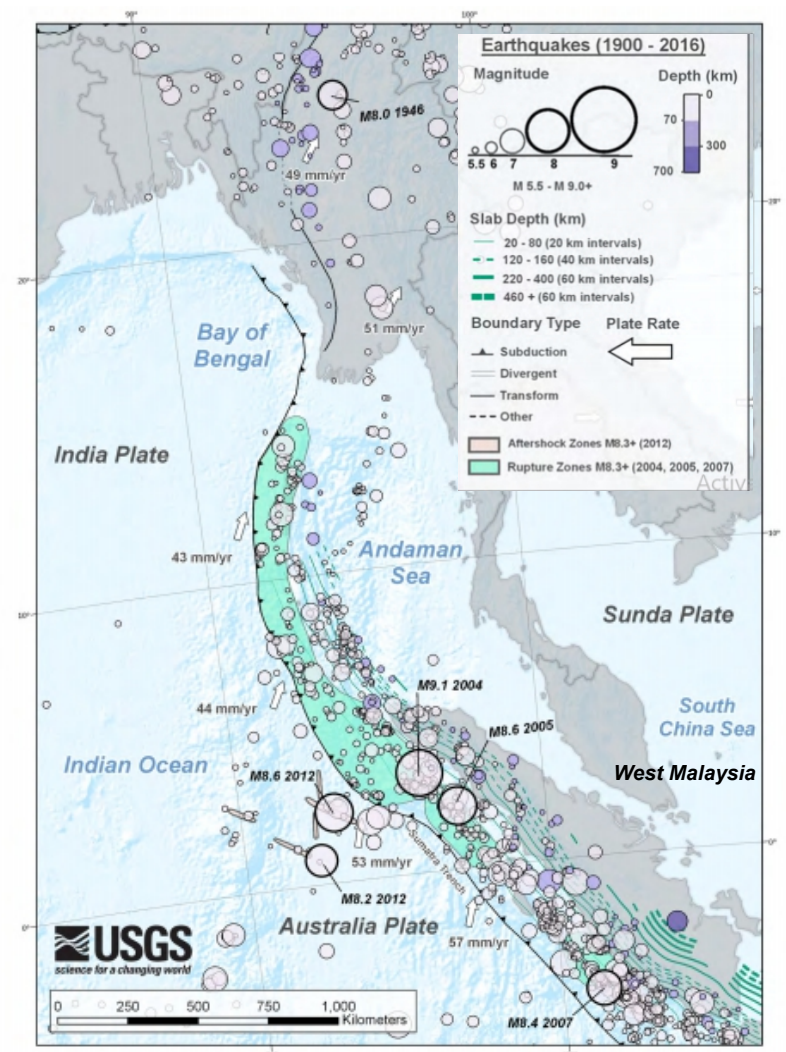

Figure 1 Map of tectonic summary region [9]

Before year 2004 [3], Malaysia was assumed to be lucky and safe from local and far field earthquakes due to its location away from ring of fire [4]. However, the occurrence of catastrophic regional disaster year 2004 Indian Ocean Earthquake with a magnitude of Mw 9.1 brought devastating impact through tsunami and caused 68 Malaysian citizens lost their life [5]. Such a massive earthquake was followed by multiple aftershocks from year 2005 till now [6], which referred that after such disastrous event, the inactive fault lines were reactive and can create destruction in West Malaysia from local near field earthquake too [7].

Malaysia identified to be a low seismic area [10] that's why most of the reinforced concrete structures were designed on wind lateral load. Less than one percent of building structures were design on earthquake loads [10]. Secondly, majority of building structures in Malaysia were design on British Standard BS8110 [11] which do not have any provision for earthquake [2], [12]. In year 2002, Institute of Engineers Malaysia IEM organization had suggested to adopt Euro code [13] and replace it with British Standards as a structural code in Malaysia [14]. Still up to date, most of the states in Malaysia is following BS code.

Previous studies identify that $50 \%$ of Peninsular Malaysia building structures were came across the concrete deterioration [15] which is due to the seismic ground motion vibrations originated from far or near field. Current practice to analyze or design a building such as FEMA 368 and EC8 underestimated the effect of repeated excitations [16]. These guidelines only consider single vibrations to evaluate the framed structure [2]. In the past studies, it had been observed that first tremor is being followed by multiple shocks which affect the ductility demand stronger and higher than the one with single seismic vibration [17]. Thus, the current provisions and design practices in earthquake engineering required to reconsider a procedure based on multiple seismic excitations rather than single vibration [18], [19].

In Malaysia, the seismic vibrations from far field usually disturbs the strength of RC building structures that is why most of the research studies were focusing on strength of structures and damages produced. For example, vulnerability study of public buildings subjected to earthquake event was conducted to assess the performance of two critical frame reinforced concrete buildings [20]. The study indicated that no structural damage was recorded due to both buildings damage index less than 1.0. A study was conducted to assess the vulnerability of a medium-rise reinforced concrete buildings located in Ipoh, Malaysia [21]. The building was analyzed using Finite Element Modeling (FEM) under variety of earthquake intensities from Time History Analysis (THA) considering 
low to medium earthquake intensities. Results concluded that there are different damage levels that affect the frames when different intensities are applied by looking at structural and non-structural damage. Ismail et al. [22] addressed the performance of highrise building present in Malaysia by simulating the four building model in Finite Element Modeling (FEM). Simulation results concluded that complete collapse of building model held at $1 \mathrm{~g}$. Another study was conducted on six reinforced concrete buildings which were mostly categorized as medium-rise moment resisting frames had been selected for damage assessment [23]. A variation of low earthquake intensities $(0.05 \mathrm{~g}, 0.10 \mathrm{~g}, 0.15 \mathrm{~g}, 0.2 \mathrm{~g})$ had assessed the building model in simulation software Finite Element Modeling (FEM). Study declared that at earthquake motion $0.2 \mathrm{~g}$, there were no structural damage. One more study presented an evaluation of high rise building in Kedah which was subjected to low intensity earthquakes effects [24]. The building was analyzed using Finite Element Modelling (FEM). The building performed the early yielding point at $3.115 \mathrm{~s}$ for beam element at intensity $0.20 \mathrm{~g}$ however there was no structural damage. Ismail et al. [25] selected a medium rise college building located in Johar. Low intense earthquake excitation was applied. At $0.15 \mathrm{~g}$, building performed the early yielding point at 4.2650 sec for beam element however building model survive till $0.2 \mathrm{~g}$ and there was no structural failure recorded. A study addressed a vertical geometric irregularity frame structures of seven storey building located in Selangor [26]. Seismic motion of Acheh, Indonesia on December 26, 2004 was selected to assess the building model on finite element software LUSAS. It was concluded that building model was sustainable and performed well under Acheh ground motions. A building model was investigated to check the condition for soft storey and the appearance of plastic hinges in reinforced concrete specimen during sequential ground motions which includes Ranau earthquake seismic vibration [4]. The study showed that soft storey structure had the lowest seismic resistance and collapses at $0.55 \mathrm{~g}$ PGA.

A 3 storey hospital building had been analyzed by multiple seismic loadings [3]. Their study depicts that bending moment and shear force caused by high intensity of seismic load were highest compared to other intensities. The changing of maximum bending moment and shear force due to high seismic load applied compared to action of gravity load only was very high up to $82.4 \%$ and $13.2 \%$ respectively. Study concluded that the low rise hospital building can withstand any type of seismic load [3].

In the past, several studies have been conducted focusing on Malaysian RC structures along with behavior factor ' $q$ ' ranging from 1 to 6 against multiple seismic ground motions. For example, an 18 storey high rise RC building had been assess with near field earthquakes. Five generic simulated model were examined with multiple ground motions. The study concluded that high rise building would significantly being effected by multiple ground motions as compared to single earthquake [27]. The increase of displacement and storey ductility demand increase as the behavior factor, $q$ increases. A study on a nonlinear behavior of low rise three storey reinforced concrete building structure had conducted which include near and far field earthquakes of Sabah, Malaysia [6]. Study included behavioral factor which is also known as force reduction factor used to reduce the forces obtained from Linear analysis [28] and also decrease the ductility class [29]. Results concluded that interstorey drift increases as the behavior factor increases. Near field earthquakes had greater interstorey drift as compared to far filed earthquake [6]. Another study examined the performance of 3 and 18 storey building model respectively. Behavioral factor vary between 1 to 6 along with single and multiple excitations had been performed [16]. They found that level of behavior factor was strongly affecting the interstorey ductility demand and magnitude of maximum inter storey drift ratio for both 3 and 18 storey models.

A two storey RC general office buildings had been redesigned from BS8110 to EC8 for multiple seismic ground motion to investigate the increment of total cost of material if seismic design has to be implemented in Malaysia [15]. The study suggested that Ductility Class Medium DCM approach is not practical to be implemented for seismic design in Malaysia for low rise RC building due to extremely high increment of total cost of materials in range of 1.7 to 3.3 times compared to current practice. Another study assessed the increment in cost of building with and without seismic design in accordance with BS81 10 [11] and Eurocode 2. A total of 8 building model of 2 storey had been drawn considering four different peak ground acceleration $0.02 \mathrm{~g}, 0.06 \mathrm{~g}, 0.12 \mathrm{~g}$ and $0.25 \mathrm{~g}$ [2]. Nonlinear time history analysis was also performed for single and far field repeated excitations. It was concluded that soil of class D can increase the cost of seismic resisting building model with a behavior factor of 1.5 as mentioned in Eurocode EC8. The rise in cost is 6 to $72 \%$ [2]. In current practice, by following the BS8110 code will lead to $270 \%$ unacceptable incremental cost of material by considering the behavioral factor as 1 [2]. Secondly, the repeated excitation will increase 8 to $29 \%$ of interstorey drift as compared to single excitation [2]. A 2D framed building model with 3, 6 and 9 storey regular structures were designed on DCM requirements. The study concluded that interstorey drift and maximum storey had influence on building model under repeated ground motions [30].

In the light of above discussions, particularly in Malaysia, all the previous studies were focusing on simulated program however no one have analyzed a low-rise three dimensional RC framed structure experimentally. This study is unique because harmonic ground motions (artificial motions) are selected with short intervals between consecutive seismic excitations. In this study, a two storey 3D reinforced concrete building frame structure is examined through artificially produced sequential ground motions with a scenario 
of pre shock, main shock and after shock ranging PGA values from $0.18 \mathrm{~g}$ to $0.82 \mathrm{~g}$ investigated on Shaking table. To fulfill this objective, actual prototype frame structure is scaled down with the help of similitude technique Buckingham Pie theorem. Thereafter, the scaled down framed specimen is placed on Shaking table and then asses for multiple ground motions. The building performance was measured in terms of damage features and displacement response. The outcome of this study contribute to the society in the formulation of European Code 8 National Annex in near future for structural seismic resistance design.

\subsection{METHODOLOGY}

In this study, a small segment of educational institute building model of Block $N$, Universiti Tunku Abdul Rahman, Malaysia is scaled down to $1 / 10$ and then examined on shaking table. Similitude technique Buckingham Pie Theorem is used to calculate scaling factors to scale down the actual prototype building as shown in Figure 2.

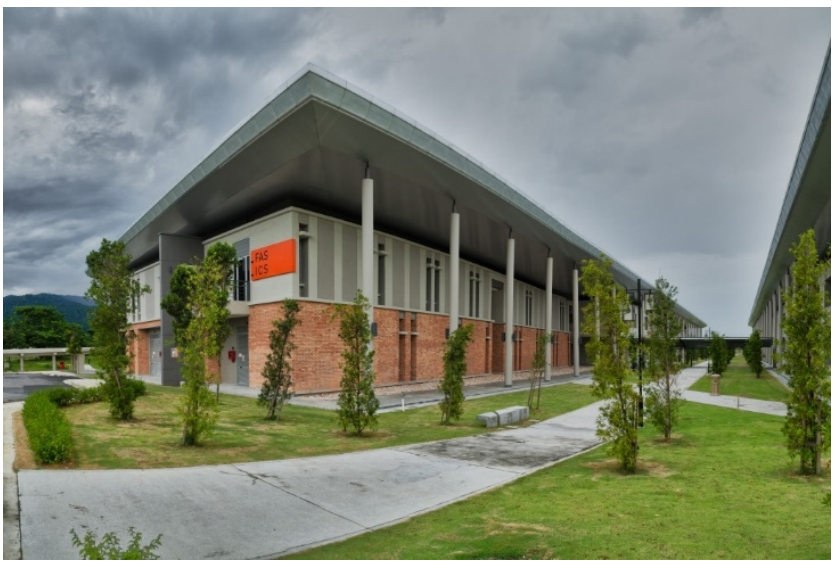

Figure 2 Prototype full scale building model located in Block N, Universiti Tunku Abdul Rahman, Perak, Malaysia

\subsection{Buckingham $\pi$ Theorem}

Dimensional analysis is the foundation for Buckingham's $\pi$ theorem. There must be dimensional homogeneity among the variables. Consider a nondimensional parameter named $\mathrm{Pi}(\pi)$. In a general dimensional analysis problem, Dependent $\mathrm{Pi}$ symbolizes as $\pi_{1}$. Remaining Pi's ( $\pi$ 's) are independent as there are function to $\pi_{1}$ as shown below.

$$
\Pi_{l}=f\left(\Pi_{2}, \Pi_{3}, \ldots, \Pi_{k}\right)
$$

Where, ' $k$ ' is the total number of Pi's.

\subsection{Similitude Methodology of Structural Model}

Consider a building model having 10 physical parameters (dimensional variables, no dimensional variables, and dimensional constants) therefore, $n=10$. These parameters are shown in functional form as shown below [32]:

$$
\sigma=f(d, t, \rho, E, g, l, V, \Omega, v)
$$

Where, $\sigma=$ stress, $d=$ displacement,$t=$ time, $\rho=$ density, $E=$ modulus of elasticity, $g=$ spectral acceleration, $I=$ length, $V=$ Shear Force, $\Omega=$ Frequency, and $v=$ velocity.

Following are the Primary dimensions of each ' $n$ ' parameters as shown in Table 1 [32].

Table 1 Dimensions of Selected Parameters

\begin{tabular}{ll}
\hline Quantities & Dimensions \\
\hline$\sigma$ & $F^{-2}$ \\
$d$ & $L$ \\
$t$ & $T$ \\
$\rho$ & $F T^{2} L^{-4}$ \\
$E$ & $F^{-2}$ \\
$a$ & $L T^{-2}$ \\
$g$ & $L T^{-2}$ \\
$l$ & $L$ \\
$V$ & $F L^{-2}$ \\
$\Omega$ & $T^{-1}$ \\
\hline
\end{tabular}

\subsection{Similitude Relations}

Drawing the different similitude relationships and scale factors for dynamic structural model, is shown in Table 2. Different parameters have been scaled down. Dimensional Scale factor ' $S$ ' and ' $S_{E}$ ' are used to reduce the model scale. Typical scale factor for Slab/beams structures for elastic models is 1:10 [33]. The detail calculation for scaling factor ' $S_{E}$ ' and similitude relationship was studied in Haider et al. [34]. Material properties for prototype and scaled model remains similar i.e $S_{E}=9.9$ as calculated in Haider et al. [34]. Table 2 shows the reduced model parameters.

Table 2 Similitude relation

\begin{tabular}{llll}
\hline \multicolumn{1}{c}{ Parameters } & Dimensions & \multicolumn{2}{c}{ Scale Factor } \\
\cline { 3 - 4 } & & $S_{E}$ & 9.9 \\
& & Equations & \multicolumn{1}{c}{$\begin{array}{c}\text { Scale up } \\
\text { Model }\end{array}$} \\
\hline Modulus, $E$ & $F L^{-2}$ & $S_{E}$ & 9.9 \\
Stress, $\sigma$ & $F L^{-2}$ & 1 & 1 \\
Acceleration, $a$ & $L T^{-2}$ & $S$ & 10 \\
Length, I & $L$ & $S_{E} S^{2}$ & $9.9^{*}(10)^{2}$ \\
Point load, $P$ & $F$ & $S_{E} / S$ & $9.9^{*}(10)^{-1}$ \\
Mass Density, $P$ & $F L^{-4} T^{2}$ & $S_{E} S^{2}$ & $9.9 *(10)^{2}$ \\
Shear force, $V$ & $F$ & $S_{E} S^{2}$ & $9.9^{*}(10)^{2}$ \\
Moment, $M$ & $F L$ & &
\end{tabular}




\subsection{General Specification}

The shape of the building is regular and symmetrical. Structural building design code EC2 and EC8 is considered. Dimensions of column and beam for small scale model are $60 \mathrm{~mm} \times 40 \mathrm{~mm}$ and $60 \mathrm{~mm} \times 25 \mathrm{~mm}$. Height of each floor and section details are shown in Figure 3.

Seismic analysis method known as nonlinear dynamic time history analysis is performed.

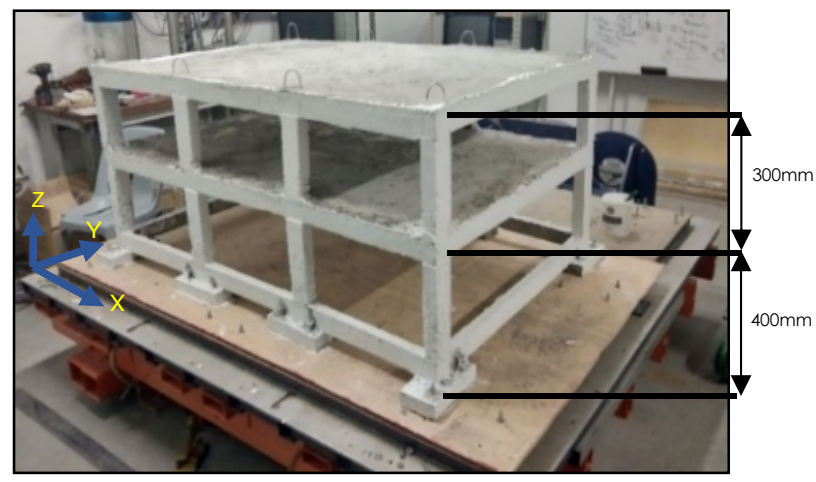

Figure 3 (a)
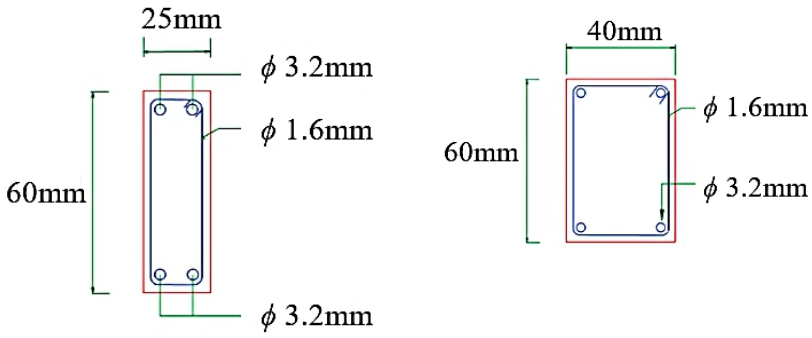

Figure 3 (b)

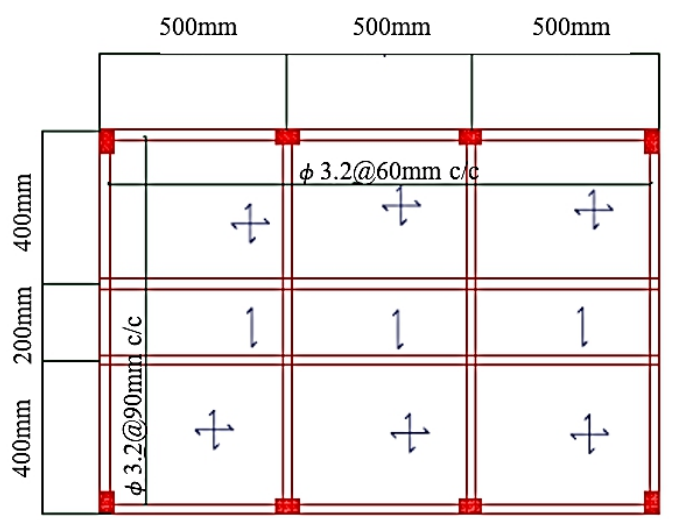

Figure 3 (d)

Figure 3 (a) Scaled down building model; (b) Beam Reinforcement details; (c) Column Reinforcement details; (d) 1st and 2nd storey Slab reinforcement and Plan layout
Number of Stories: 2

Number of bays in $X$ direction:

Number of bays in $Y$ direction:

Grade of Concrete:

Damping:

Grade of Steel:

Importance factor:

Behaviour factor:

Instrument allocation and Earthquake vibration data Contact sensor Accelerometers and Linear Variable Displacement Transducer (LVDT) are attached to shaking table as shown in Figure 4 to record acceleration and displacement produced.

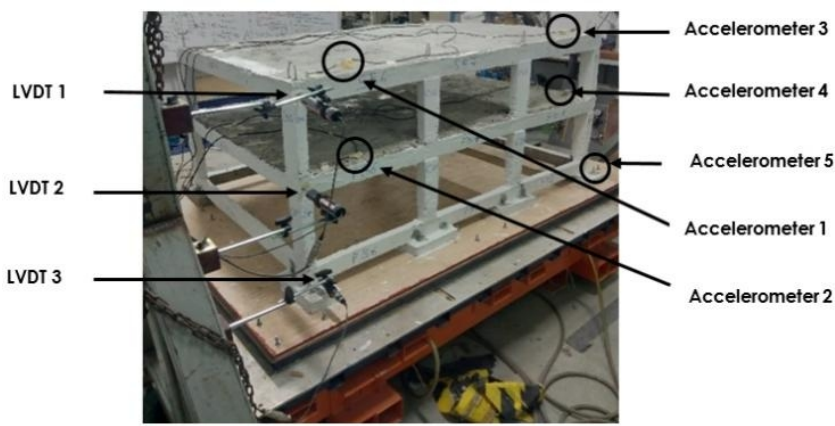

Figure 4 Placement of Accelerometers and LVDT on Framed structure

Multiple combination of input frequency and displacement are used to generate multiple ' $g$ ' values as shown in Table 3. Here, the tests have been categorized in three types of seismic vibrations that is pre-shock, main shock and after shock. Moreover, seven sequential ground motions have been selected due to the requirement mentioned by FEMA 356 (Clause 3.3.2.2.4) for nonlinear time history analysis.

Figure 5 shows that the peak ground acceleration generated by shaking table are ranging from $0.18 \mathrm{~g}$ to $0.82 \mathrm{~g}$. All these time histories had been applied sequentially with time interval of $10 \mathrm{sec}$ between the two consecutive ground motions.

Table 3 Test Sequences

\begin{tabular}{llllll}
\hline & \multicolumn{1}{c}{ Test case } & & Input motion & PGA (g) \\
\cline { 3 - 5 } & & & Frequency $\mathbf{( H z )}$ & Displacement (mm) & 0.25 \\
\hline Pre-shock & Test 1 & 3 & 1.5 & 0.30 \\
& Test 2 & 5 & 0.5 & 0.36 \\
& Test 3 & 3 & 2.0 & 0.3 \\
\hline
\end{tabular}




\begin{tabular}{lllll}
\hline Main shock & Test 4 & 10 & 0.5 & 0.64 \\
& Test 5 & 8 & 0.5 & 0.82 \\
\hline After shock & Test 6 & 5 & 0.5 & 0.24 \\
& Test 7 & 2 & 3.0 & 0.18 \\
\hline
\end{tabular}

Test 1

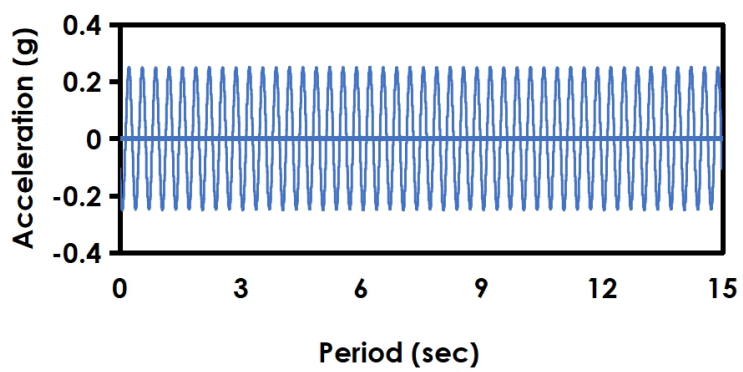

Test 3

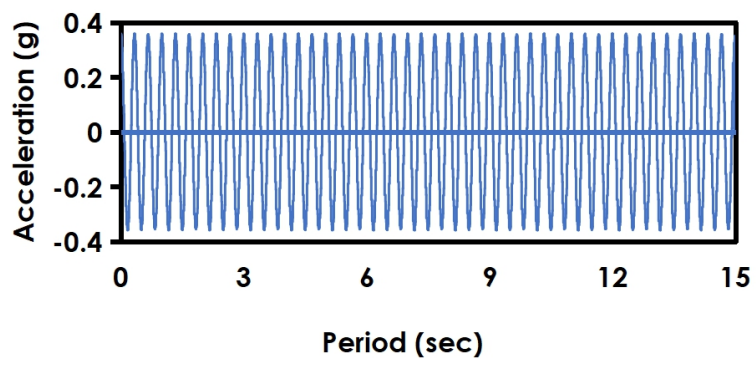

Test 5

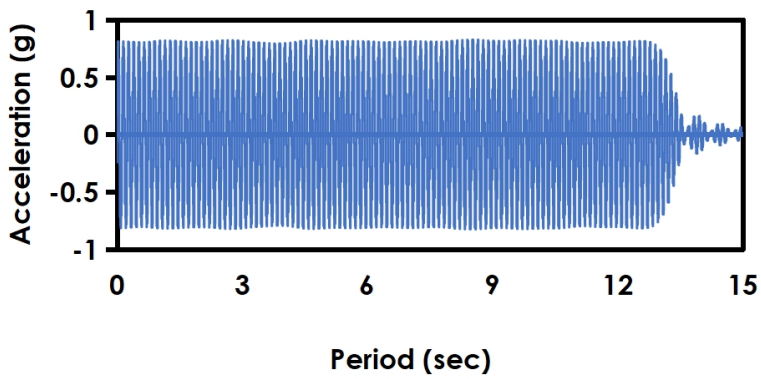

Test 2

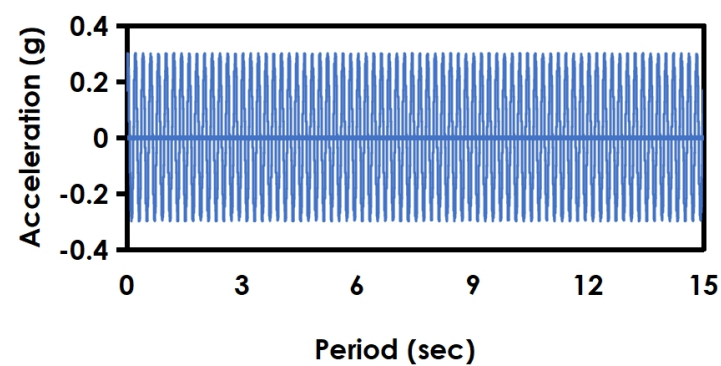

Test 4

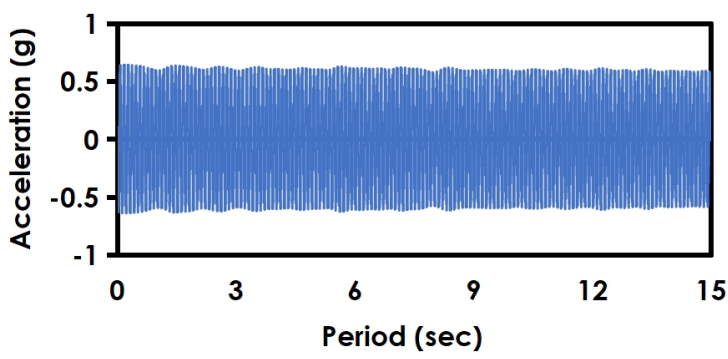

Test 6

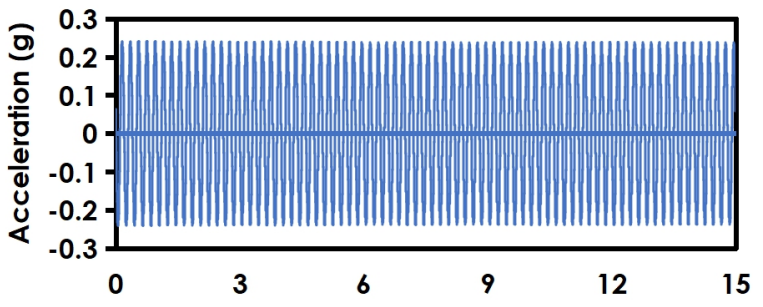

Period (sec)

Test 7

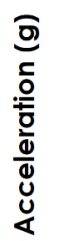

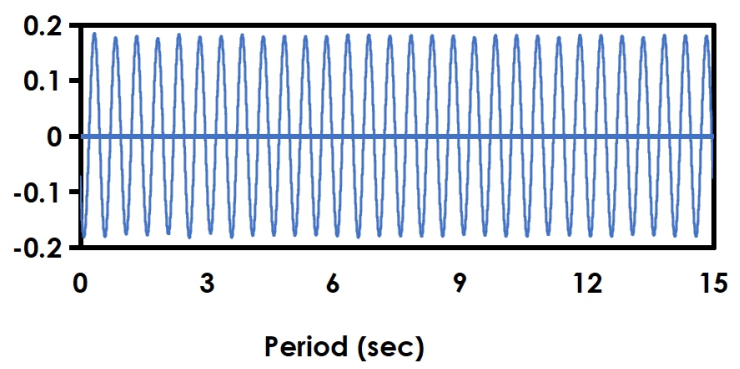

Figure 5 Time history of uniform harmonic seismic excitation applied sequentially from Test 1 to Test 7 


\subsection{RESULTS AND FINDING}

In The experimental results presented in this section includes the observed dynamic behavior of the tested framed model, cracks appeared in joints of beam and column, damage indexing and displacement responses. Moreover, the building model has passed through multiple seismic excitations. Therefore, the structural behavior in all test cases of seismic motion have been discussed in this section.

\subsection{Cracks Pattern and Damage Indexing}

The down-scaled frame structural model underwent to seven sequentially input ground motion acceleration while subjected to observed cracks and large displacement. The initial and minor cracks are observed after seismic excitation Test 3 followed by major crack at Test 4 and 5 . Before Test 4 , three seismic excitation Test 1, 2 and 3 ranging from 0.25 to $0.36 \mathrm{~g}$ were attempted to see the structural behavior before Test 4 and 5. From seismic excitation Test 3 , the joints of column and beam at storey 1 indicates that concrete stress has exceeded its tensile strength. As the ground motion acceleration increases from 0.64 to $0.82 \mathrm{~g}$, newbie cracks are formed at corner and joints of beam column, above and below the beams. Moreover, the old cracks are further propagated and becomes more noticeable. After the seismic excitation Test 4 and 5 , the framed specimen undergoes to Test 6 and 7. Secondly, in order to calculate the damage index for each test case, Park-Ang [35] Damage Index (DI) is computed. Park-Ang classifies the damage stage into five different levels of indexing.
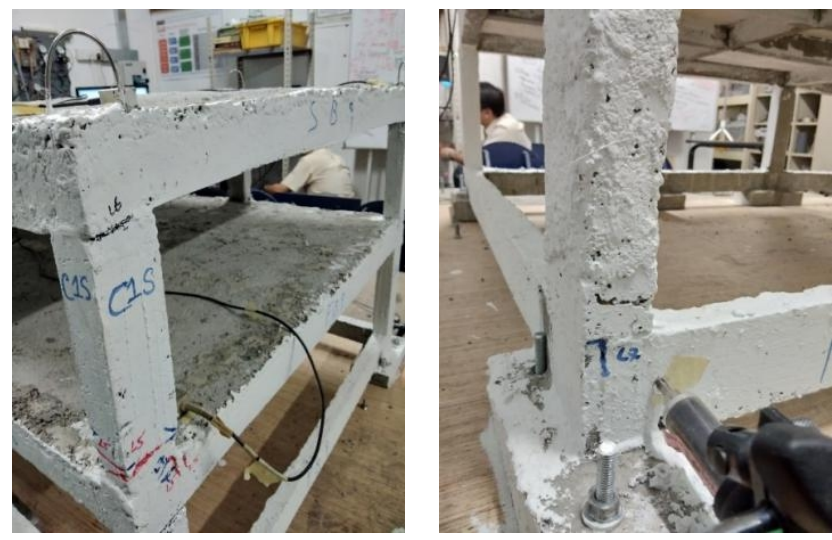

Figure 7 Horizontal and vertical cracks in columns of base and storey 2

$\mathrm{DI}<0.1$ : No damage or localized minor cracking. $0.1 \leq \mathrm{DI}<0.25$ : Minor damage: light cracking throughout.

$0.25 \leq \mathrm{DI}<0.40$ : Moderate damage: severe cracking, localized spalling.

$0.4 \leq \mathrm{DI}<1.00$ : Severe damage: concrete crushing, reinforcement exposed.

$\mathrm{DI} \geq 1.00$ : Collapse.
These ranges show that RC structure is in an elastic state if damage index (DI) is above zero however collapse occurs after damage index (DI) cross 1.0 and above without no upper limit suggested. In the framed specimen at Test 3, the material of building model starts to deteriorate which indicates that DI is ranging between 0.0 to 0.09 . There is no damage observed at base and roof of the framed specimen. Only storey 1 have minor cracks as shown in Figure 6. Particularly intermediate beams and columns have no effect of seismic motion. As we know that seismic motion has an impact from base to the roof, therefore, it starts inducing the damage at a weak storey that is storey 1 in this study.
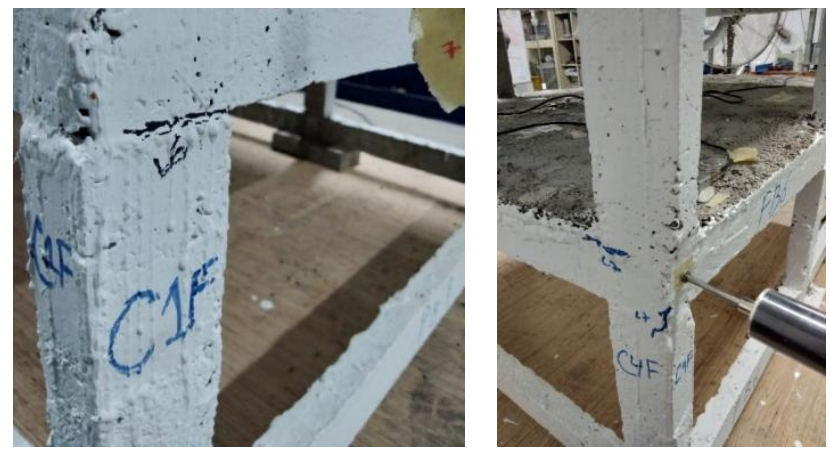

Figure 6 Horizontal and diagonal minor cracks observed at storey 1 in Test 3

At Test 4, the test model damage behavior is followed by horizontal, vertical and diagonal cracks at the beam-column joint panel and corner at storey 1 as shown in Figure 7. The cracks are formed because due to transferring moments from beams end to columns' ends. This damage pointed to the concrete material yield strength at beam and column. Moreover, the model is observed with significant flexural horizontal cracks in the beam-column joint on the roof storey as shown in Figure 7. Minor cracks are observed at base. Still intermediate columns and beams have not shown any significant damage behavior during this ground motion excitation. Additionally, the damage index is moved to the second stage that is $0.1 \leq \mathrm{Dl}<0.25$ (Minor damage).

During the run of Test 5, the model has experienced significant flexural cracks at beamcolumn joint at base and storey 1 which is the extension of cracks propagated in Test 6 as shown in Figure 8. 

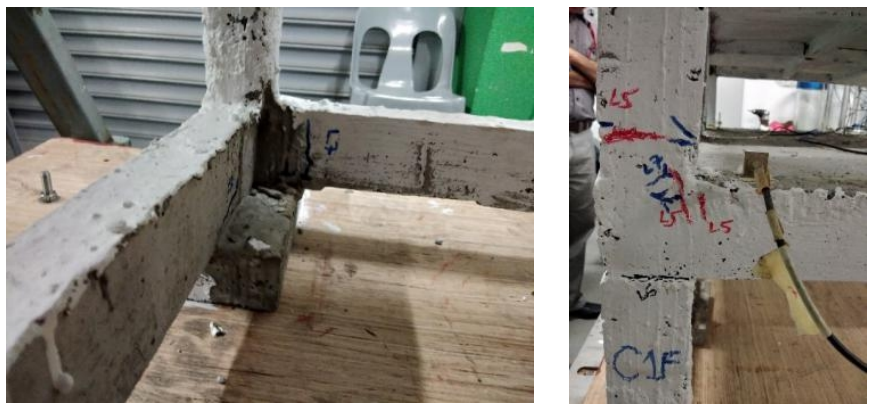

Figure $\mathbf{8}$ Significant crack patterns at base and storey 1

At this ground motion, intermediate columns and beams of tested framed specimen has experienced cracks as shown in Figure 9. However, there is no spalling of concrete which indicated the damage index still remain in the second stage that is $0.1 \leq \mathrm{DI}<$ 0.25 (Minor damage). Moreover, as Test 5 has maximum PGA value that is $0.82 \mathrm{~g}$ that is why the frequency of vibration is high however the test specimen sustains and absorb vibrations without any structural member failure.

After test specimen undergoes from ground motion seismic excitations ranging from 0.25 to $0.82 \mathrm{~g}$ (seismic excitation Test 1, 2, 3, 4, and 5), the test framed specimen is subjected to PGA values of $0.24 \mathrm{~g}$ and $0.18 \mathrm{~g}$ (Test 6 and 7 ). In seismic excitation Test 6 , there is further propagation of new cracks. The test specimen is shifting its state from minor to moderate damage. Thus, damage index is in a process of crossing 0.24 and reached to the range of $0.25 \leq \mathrm{DI}<$ 0.40. In Figure 10, it can clearly see that, in Test 7 , the framed specimen is subjected to concrete deterioration and significant cracks at beams (intermediate and periphery) can be observed. The test specimen losing its strength and further propagate the cracks occur in the previous test. Subsequently, in Test 7, the framed specimen has a severe crack and moderate damage which make the RC structural model to lie in damage index ranging from $0.25 \leq \mathrm{Dl}<$ 0.40 .
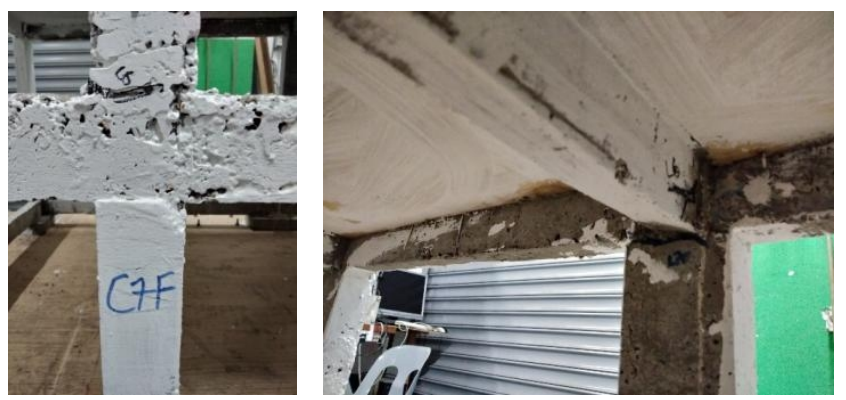

Figure 9 Horizontal cracks at beam-column joints
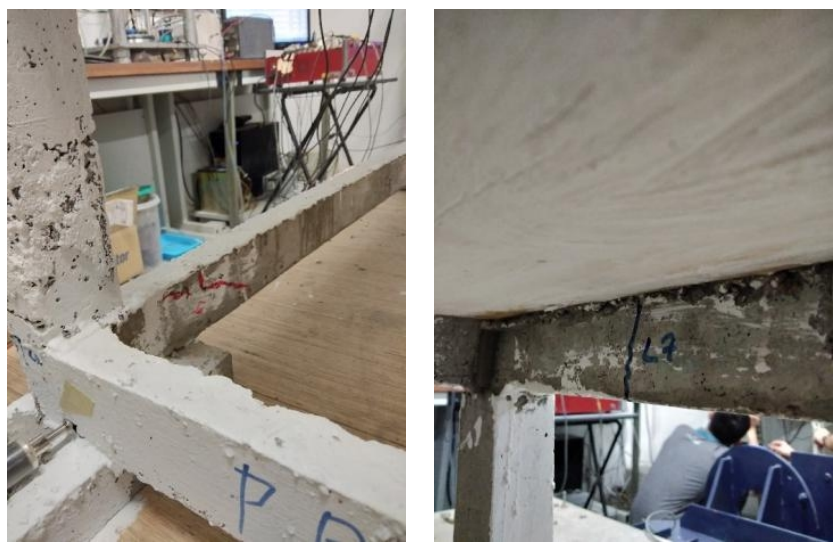

Figure 10 Propagation of cracks in Test 7

Thus, under incremental seismic ground motion, concrete material deterioration starts from weak storey followed to damage in the adjacent storey either upper or lower storey due to the impact of inertial forces in the horizontal direction. Frame structure has damage concentration at beam-column joints. The damage is less severe especially at the roof (storey 2) as going up along the elevation in the frame structural building model because the storey 1 is mostly absorbing the seismic vibrations and could not transfer the ground motion frequencies completely till the roof (storey 2). By the end of the test, there is no sign of reinforcement failure. No structural failure has been recorded other than concrete material deterioration. Framed specimen reaches to the DI ranging from 0.25 $\leq \mathrm{DI}<0.40$ having moderate damage to the RC structure and does not allow deformation state. It is concluded that building model shows resistance to multiple ground motions and perform well by sustaining its structural strength.

\subsection{Acceleration Response}

Figure 11 shows the acceleration time histories of 1st and 2 nd stories from the test 1,2 and 3 (pre-shocks). In test 1 and 2, the concrete material of framed specimen does not reach to its yield point. The maximum acceleration recorded at story 1 in test 1 and 2 are $2.7 \mathrm{~m} / \mathrm{s}^{2}$ and $3.6 \mathrm{~m} / \mathrm{s}^{2}$. Similarly, maximum acceleration $2.4 \mathrm{~m} / \mathrm{s}^{2}$ and $3.5 \mathrm{~m} / \mathrm{s}^{2}$ had recorded at storey 2 in test 1 and 2 . Furthermore, in test 3 , it is observed that test frame specimen starts to yield its concrete material and slightly damaged. It approaches to maximum acceleration $4.0 \mathrm{~m} / \mathrm{s}^{2}$ and $3.6 \mathrm{~m} / \mathrm{s}^{2}$ at storey 1 and 2 . It is noticeable that in each test, the acceleration had higher values at storey 1 as compared to storey 2 because storey 1 had loaded with a weight of storey 2 which is $124.22 \mathrm{~kg}$ however there was no storey load above storey 2 which makes the storey 1 critical. Moreover, the seismic waves produced by shaking table are not properly transferred from storey 1 to storey 2 which cause the 
framed structure to create a scenario of soft storey at storey 1.

Thereafter, the damage developed progressively in main shocks from Test 4 to 5 . In test 4 , it is observed that the building model base is accelerated to 7.7 $\mathrm{m} / \mathrm{s}^{2}$ which causes the roof to accelerate $15.7 \mathrm{~m} / \mathrm{s}^{2}$ as shown in Figure 12. It is observed that the framed specimen got damaged due to high value of ' $g$ '. Similarly, in test 5 , the test model accelerated at 12.6 $\mathrm{m} / \mathrm{s}^{2}$ from roof and extend the cracks in framed model.
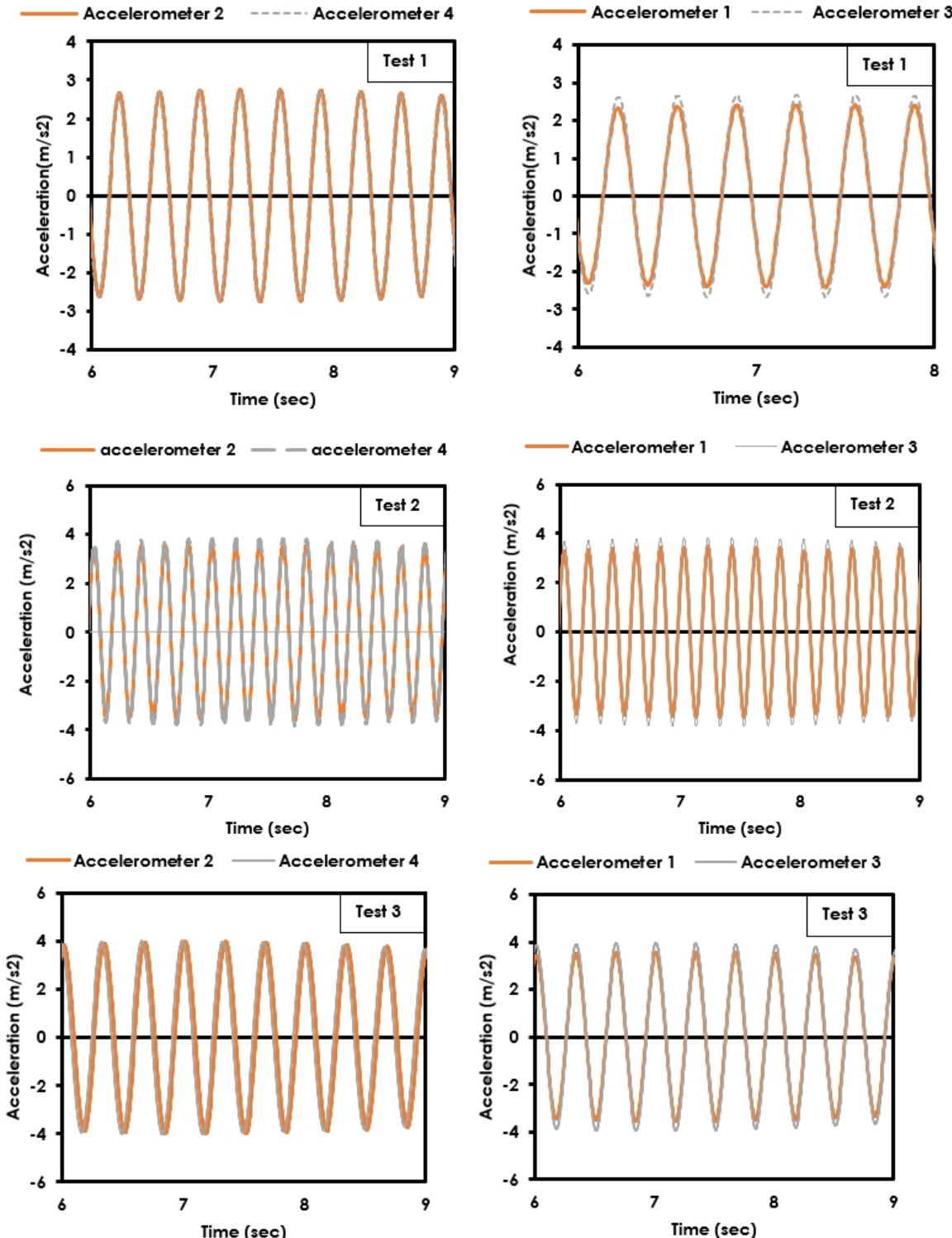

(a) 1st Storey (Intermediate Storey)

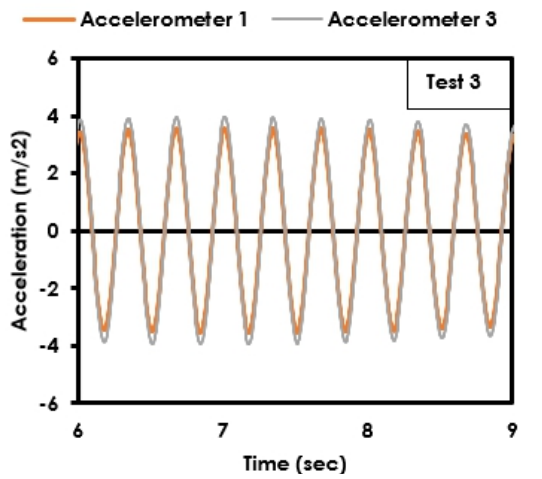

(b) 2nd Storey (roof)

Figure 11 Acceleration time histories at 1st and 2 nd stories in Test 1,2 and 3 (Pre-shock) (Continue) 

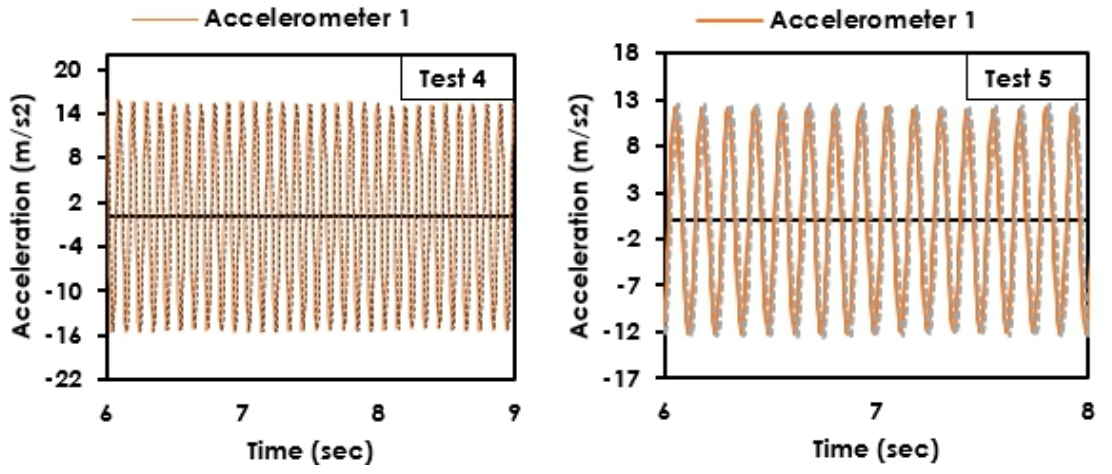

(a) Storey 2 (roof)
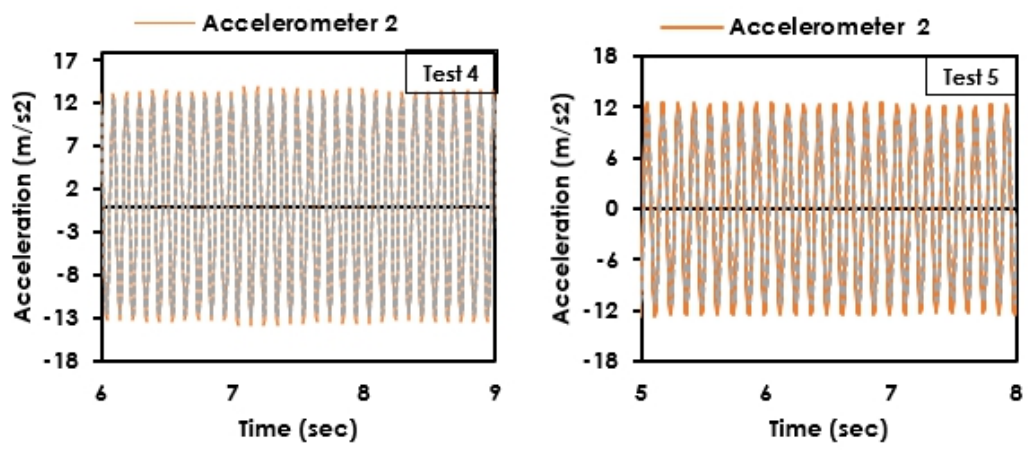

(b) Storey 1 (intermediate storey)
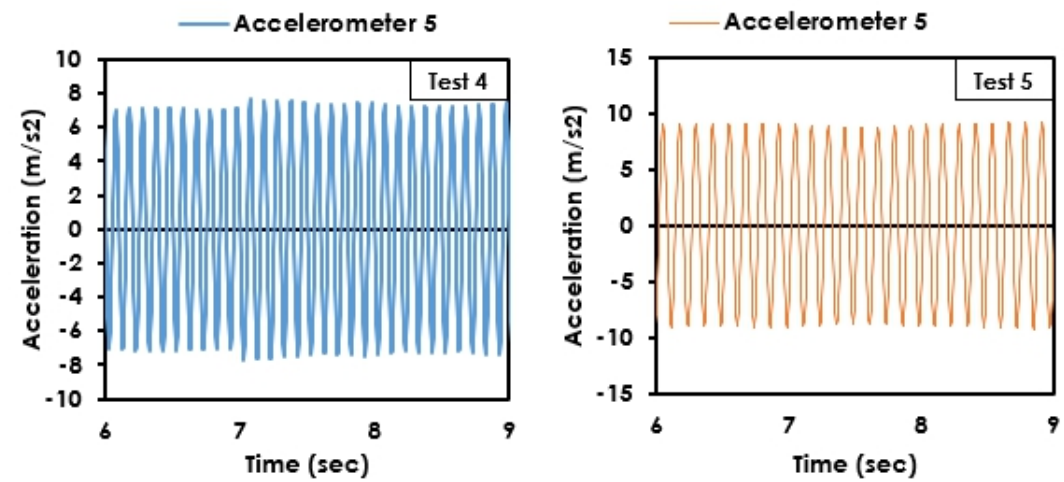

(c) Base

Figure 12 Acceleration time histories in Test 4 and 5 (Main-shock) (Continue)
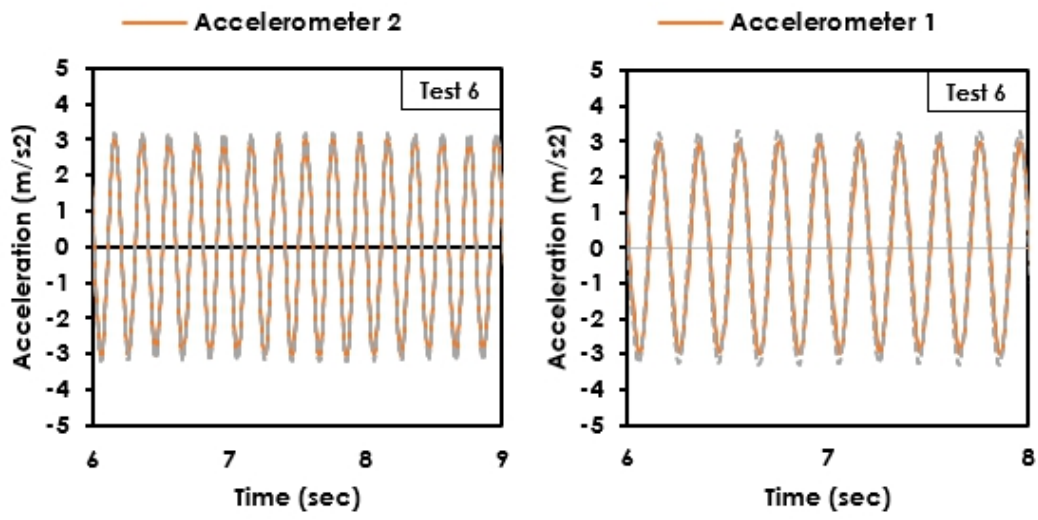


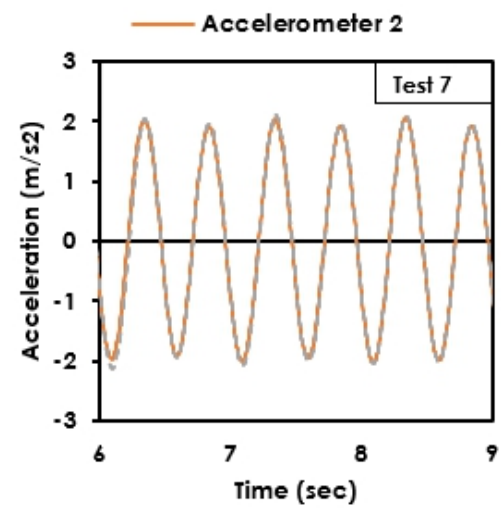

(a) 1st Storey (intermediate storey)

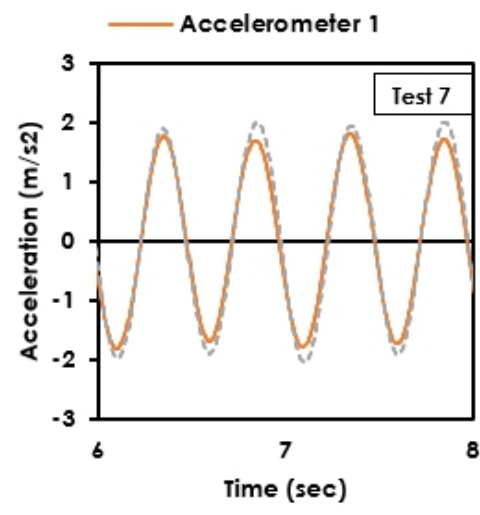

(b) 2nd Storey (roof)

Figure 13 Acceleration time histories at 1st and 2nd stories in Test 6 and 7 (aftershock)

The test framed specimen has gone through multiple excitations. In total, 5 sequential ground motions (pre-shocks and main shocks) have been applied ranging from 0.25 to $0.82 \mathrm{~g}$. Now, the building model is ready to test for aftershocks (Test 6 and Test 7). Figure 13 shows the acceleration behavior of framed specimen for intermediate and roof storey. In test 6 and 7 , it is again observed that building model have higher acceleration in storey 1 as compared to storey 2, same as observed in Test 1, 2 and 3. Therefore, it has been concluded that building model with lower PGA values have an effect of soft storey and make the model to accelerate more in storey 1 in correlation with storey 2.

\subsection{CONCLUSION}

A shaking table test was conducted to collect the realistic structural responses of a RC frame structure that predict the behavior of building model from lower to high Peak Ground Acceleration (PGA) values. Accelerometers were utilized to record the acceleration response in each sequential ground motion. The main objective of this research is to produce a fully documented benchmark test program which could be used to verify the analytical or numerical results regarding the effects of multiple shock earthquakes on global structural response. The test program can also provide a better understanding of progressive behavior of low-rise RC frame structures especially in Malaysia. Study outcomes indicated that the maximum damage index recorded for low rise RC building model was $0.25 \leq \mathrm{Dl}<0.40$ (moderate damage) which clearly showed that model survived after intense level of seismic sequences. Moreover, the first three PGA's and last two PGAs had identified that storey 1 is soft storey because the acceleration of storey 1 was slightly higher than storey 2(roof) because storey 1 had loaded with a weight of storey 2 which is $124.22 \mathrm{~kg}$, however, there was no storey load above storey 2 which makes the storey 1 critical. Findings also highlighted that intermediate beam and column did not respond and shown any cracks before test 3 which indicated that building model did not response to increasing test level of ground motion acceleration ranging from 0.24 to $0.36 \mathrm{~g}$. The test frame specimen faced increasing levels of damage as seismic excitation become more severe especially at test level 5 and 6 with PGA values of $0.64 \mathrm{~g}$ and $0.82 \mathrm{~g}$.

\section{Acknowledgements}

The authors acknowledge the financial support through UTAR-RF grant no. IPSR/RMC/UTARRF/2016Cl/Zl provided by Universiti Tunku Abdul Rahman (UTAR), Perak, Malaysia.

\section{References}

[1] M. R. Che Abas. 2001. Earthquake Monitoring in Malaysia. Seism. Risk Semin. Malaysia. Seismological Division, Malaysian Meteorological Service.

[2] M. I. Adiyanto and T. A. Majid. 2014. Seismic Design of Two Storey Reinforced Concrete Building in Malaysia with Low Class Ductility. J. Eng. Sci. Technol. 9(1): 27-46.

[3] M. I. Adiyanto, T. A. Majid, and S. Zaini. 2008.bAnalysis and Design of 3 Storey Hospital Structure Subjected to Seismic Load Using STAAD PRO. Int. Conf. Constr. Build. Technol. 35: 377-388.

[4] C. G. Tan, W. T. Chia, T. A. Majid, F. M. Nazri, and M. I. Adiyanto. 2017. Soft Storey Effects on Plastic Hinge Propagation of Moment Resisting Reinforced Concrete Building Subjected to Ranau Earthquake. AIP Conf. Proc. 1892. Doi: $10.1063 / 1.5005748$.

[5] H. Lye, S. Yean, P. Li, F. Liu, A. Izani, and H. Ling. 2009, Simulation of Andaman 2004 Tsunami for Assessing Impact on Malaysia. J. Asian Earth Sci. 36(1): 74-83. Doi: 10.1016/j.jseaes.2008.09.008.

[6] T. A. Majid, M. I. Adiyanto, and F. M. Nazri. 2014. Nonlinear Response of Low Rise Hospital RC Building in Malaysia Due to Far and Near Field Earthquake. J. Civ. Eng. Res. 4(3A): 130-134. Doi: 10.5923/c.jce.201402.22.

[7] A. Marto and F. Kasim. 2013. Seismic Impact in Peninsular Malaysia Seismic impact in Peninsular Malaysia. 5th Int. Geotech. Symp. May: 237-242. Doi: 10.13140/2.1.3094.9129.

[8] M. I. Adiyanto, T. A. Majid, and F. M. Nazri. 2017. Nonstructural Damages of Reinforced Concrete Buildings due to 2015 Ranau Earthquake. AIP Conf. Proc. 1865. Doi: $10.1063 / 1.4993403$. 
[9] United States Geological Survey database (USGS). Retrived April 6, 2016.

[10] S. Z. Sooria, S. Sawada, and H. Goto. 2012. Proposal for Seismic Resistant Design in Malaysia: Assessment of Possible Ground Motions in Peninsular Malaysia. Annu. Disas. Prev. Res. Inst. 55B.

[11] British Standard. 1997. Structural Use of Concrete-Part 1: Code of Practice for Design and Construction. BS 8110-1 1997. No. 1.

[12] K. Megawati, N. T. K. Lam, A. M. Chandler, and T. Pan. 2004. Cities Without a Seismic Code I: Hazard Assessment. 13th World Conf. Earthq. Eng. 129.

[13] European Standard. 2011. EN 1998-1 (2004) (English): Eurocode 8: Design of Structures for Earthquake Resistance - Part 1: General Rules, Seismic Actions and Rules for Buildings. 1 (2004).

[14] J. Chiang. 2015. Structural Eurocodes to Replace British Standards in Malaysia. SEGi Rev. 8(July): 5-21.

[15] M. I. Adiyanto and T. A. Majid. 2013. Influence of Behaviour Factor on Seismic Design of Two Storey Reinforced Concrete Building In Malaysian Seismic Region. Aust. J. Basic Appl. Sci. 7(8): 411-419.

[16] M. I. Adiyanto, A. Faisal, and T. A. Majid. 2011. Nonlinear Behaviour of Reinforced Concrete Building under Repeated Nonlinear Behaviour of Reinforced Concrete Building under Repeated Earthquake Excitation. 2011 Int. Conf. Comput. Softw. Model. 14.

[17] G. D. Hatzigeorgiou. 2010. Ductility Demand Spectra for Multiple Near- and Far-fault Earthquakes. Soil Dyn. Earthq. Eng. 30(4): 170-183. Doi: 10.1016/j.soildyn.2009.10.003.

[18] G. D. Hatzigeorgiou and D. E. Beskos. 2009. Inelastic Displacement Ratios for SDOF Structures Subjected to Repeated Earthquakes. Eng. Struct. 31 (11): 2744-2755. Doi: 10.1016/j.engstruct.2009.07.002.

[19] G. D. Hatzigeorgiou. 2010. Behavior Factors for Nonlinear Structures Subjected to Multiple Near-fault Earthquakes. Comput. Struct. 88(5-6): 309-321. Doi: 10.1016/j.compstruc.2009.11.006.

[20] R. Ismail, A. Ibrahim, and R. Norhazlila. 2017 Vulnerability Study of Public Buildings Subjected to Earthquake Event. MATEC Web Conf. 103(02023): Doi: https://doi.org/10.1051/matecconf/201710302023.

[21] R. Ismail and A. A. Adnan. 2016. Seismic Damage Analysis of Reinforced Concrete Frame of Public Buildings in Ipoh Subjected to Acheh Earthquake Event. InCIEC 2015. 149157.

[22] R. Ismail, A. Ibrahim, and A. Adnan. 2016. Vulnerability of
High-Rise Buildings in Kuala Lumpur Subjected to Acheh Earthquake Event. InCIEC 2015. 139-147.

[23] R. Ismail, A. Ibrahim, and A. Adnan. 2018. Damage Assessment of Medium-rise Reinforced Concrete Buildings in Peninsular Malaysia Subjected to Ranau Earthquake. Int. J. Civ. Eng. Technol. 9(7): 881-888.

[24] R. Ismail and N. F. Zamahidi. 2015. An Evaluation of High-Rise Concrete Building Performance Under Low Intensity Earthquake Effects. InCIEC 2014. 79-86.

[25] R. Ismail, M. S. Hamidah, and M. Hassim. 2014. Evaluation of Medium-rise Reinforced Concrete Building Performance under Low Intensity Earthquake Effect. Appl. Mech. Mater. 661: 106-110. Doi: https://doi.org/10.4028/www.scientific.net/AMM.661.106.

[26] R. Ismail. 2018. Seismic Performance for Vertical Geometric Irregularity Frame Structures. IOP Conf. Ser. Earth Environ. Sci. 140(1). Doi: https://doi.org/10.1088/1755-1315/140/1/012101.

[27] M. Z. A. Mohd Zahid, T. A. Majid, and A. Faisal. 2012. Effect of Repeated Near Field Earthquake to the High-Rise Rc Building. Aust. J. Basic Appl. Sci. 6(10): 129-138.

[28] European Standard. 2004. Eurocode 8: Design of Structures for Earthquake Resistance-Part 1: General Rules, Seismic Actions and Rules for Buildings. BS EN 1998-12004. 3.

[29] Uniform Building Code. 2006. International Building Code. International Code Council. USA.

[30] R. M. K. Tahara, T. A. Majid, S. S. Zaini, and A. Faisal. 2017. Effect of Repeated Earthquake on Inelastic Moment Resisting Concrete Frame. AlP Conf. Proc. 1892. Doi: $10.1063 / 1.5005650$.

[31] Y. A. Cengel and J. M. Cimbala. 2006. Fluid Mechanics: Fundamentals and Applications. McGraw-Hill.

[32] G. Rastogi, K. Moin, and S. M. Abbas. 2015. Dimensional Analysis and Development of Similitude Rules for Dynamic Structural Models. International Journal of Emerging Technology and Advanced Engineering. 5(3): 68-72.

[33] H. G. Harris and G. Sabnis. 1999. Structural Modeling and Experimental Techniques. CRC Press.

[34] S. M. B. Haider, Z. Nizamani, C. C. Yip. 2020. Non-linear Dynamic Assessment of Low-rise RC Building Model under Sequential Ground Motions. Structural Engineering and Mechanics. $\quad 74(6)$ : $\quad 789-807 . \quad$ Doi: http://dx.doi.org/10.12989/sem.2020.74.6.789.

[35] V. V Cao, H. R. Ronagh, M. Ashraf, and H. Baji. 2014. A New Damage Index for Reinforced Concrete Structures. Earthquakes Struct. April $2015 . \quad$ Doi: 10.12989/eas.2014.6.6.581. 